\title{
ANALYSIS OF THE EMPOWERMENT LEVEL OF RICE PADDY FARMERS IN ABENGGI VILLAGE LANDONO DISTRICT SOUTH KONAWE REGENCY
}

\author{
Jusman $^{1)}$, Dasmin Sidu ${ }^{2}$, Hidrawati $^{\left.{ }^{*}\right)}$ \\ ${ }^{1}$ Department of Agribusiness, Faculty of Agriculture, University of Halu Oleo Kendari 93232 \\ ${ }^{2}$ Department of Agricultural Extension, Faculty of Agriculture, University of Halu Oleo Kendari 93232 \\ *Corresponding author: hidrawati@uho.ac.id
}

To cite this article:

Jusman, J., Sidu, D., \& Hidrawati, H. (2021). Analysis of the Empowerment Level of Rice Paddy Farmers in Abenggi Vilage Landono Distric, South Konawe Regency. Jurnal Ilmiah Membangun Desa dan Pertanian, 6(6), 195 - 201. doi:http://dx.doi.org/10.37149/jimdp.v6i6.20577

Received: September 11, 2021; Accepted: December 09, 2021; Published: December 11, 2021

\begin{abstract}
Empowerment is a structured and planned process to increase the ability and independence of farmers in farm management. The study aims to analyze the program forms and the empowerment levels of lowland rice farmers. The research was conducted from April to December 2020 in Abenggi Village, Landono District, South Konawe Regency, Southeast Sulawesi. The location determination is done purposively, considering that the majority of the people work as farmers. The research population was 280 household lowland rice farmers, and the sample was $15 \%$ of the total members of the farmer population of 42 respondents. The data were analyzed qualitatively and quantitatively. Qualitatively analyze to explain the form of empowerment with research variables, including types of empowerment assistance. Quantitatively is used to determine the level of empowerment of lowland rice farmers by using variables to show economic and social empowerment, including the story of ability and independence of farmers in managing potential, planning and solving problems in the future, self-direction, and bargaining power. The results showed that the empowerment program for lowland rice farmers consists of capital assistance through the PUAP program, provision of infrastructures such as irrigation facilities, farm roads, and grain drying places. The lowland rice farmers are empowered on the economic aspect, but not yet on the social part.
\end{abstract}

Keywords: empowerment; farmers; lowland rice.

\section{INTRODUCTION}

The agricultural sector has an essential role in the economic development of society in Indonesia. Agriculture can increase employment and be the primary source of income for rural communities. Southeast Sulawesi Province, including Konawe Selatan Regency, also develops the agricultural sector. BPS Konawe Selatan (2018), there are 141,340 workers recorded, with 139,005 people working. Most of the population works in the agricultural sector, namely $53.07 \%$. However, in general, the level of empowerment of farmers in Indonesia is still low. This can be seen from the low availability of capital, the ability of farmers to access price information, access to agricultural production facilities, and the power of farmers to adopt more advanced agricultural technology, which is still low. Mangowal (2013) one aspect that can affect the success of efforts to increase agricultural output is capital. The inferior capital aspect will affect the level of farm productivity.

Environmental factors are things that humans cannot control, but the farmers themselves can govern several aspects. For example, the level of soil fertility can be increased by the use of fertilizers. Humans can control other elements, but farmers cannot fully control these aspects. This is the aspect of agricultural production prices that remain stable. Some of these factors can be owned by farmers if they have the ability or empowerment. Widjajanti (2011) Concluded that increasing the appointment of community members through an empowerment process is manifested in social capital, human capital, physical capital, and actors' ability.

To increase farmer empowerment, genuine efforts need to be made. This can be done by formulating a form of the educational program. The structure of empowerment programs can be 
capital assistance, infrastructure development assistance, regional institutional development, and strengthening and fostering business partnerships (Hutomo, 2000). When the level of empowerment of lowland rice farmers increases, it will be easier for farmers to develop their farming businesses. Anggoro and Apriyanto (2010) stated a significant relationship between community empowerment and business resilience. This aligns with Cahyono et al. (2018) opinion, which indicated that community empowerment could increase economic stability. In addition, Fischer and McKee (2017) suggest that empowered communities have resilience in managing assets, abilities, and relationships.

Research on the empowerment of lowland rice farmers has been conducted by Sadono et al. (2014), which examines the empowerment of farmers in the management of lowland rice. Widjajanti (2011) also conducted a study that concluded that increasing empowerment can be realized from social capital, human capital, physical capital, and the ability of actors. Meanwhile, Pranadji (2006) examines the empowerment of rural communities in the management of dryland agroecosystems which emphasizes providing material assistance rather than strengthening social capital. This study examines license in the form of capital assistance and production facilities and looks at the level of farmer empowerment from economic, social, and cultural aspects. This study aims to determine lowland rice farmers' form and level of charge in the Abenggi Village, Landono District, South Konawe Regency, Southeast Sulawesi. It is hoped that the results of this study can improve the results of previous studies on farmer empowerment and provide advice to the government to increase the level of community empowerment.

\section{MATERIALS AND METHODS}

The research was conducted from April to December 2020 in Abenggi Village, Landono District, South Konawe Regency, Southeast Sulawesi. The location determination is done purposively, considering that the majority of the people work as farmers. The research population was 280 household lowland rice farmers, and the sample was $15 \%$ of the total members of the farmer population of 42 respondents. The data were analyzed qualitatively and quantitatively. Qualitatively analyze to explain the form of empowerment with research variables, including types of empowerment assistance. Quantitatively it is used to determine the level of charge of lowland rice farmers by using variables that indicate economic and social empowerment. The parameters used include the level of ability and independence in managing potential, planning, and solving future problems, autonomy and bargaining power, and the ability to make decisions in the farming process.

\section{RESULTS AND DISCUSSION}

\section{Respondent Characteristics}

Based on the research results as described in Table 1, it can be seen that the age of the respondents is more dominant at the age above 50 years, as many as 22 people or $52.38 \%$. Meanwhile, young farmers were only a tiny proportion, namely nine respondents or $21.43 \%$ of the total sample in the study. The age of farmers can affect the performance of farmers in lowland rice farming. A farmer's ability at a young age will be different from the ability of farmers with old age in managing lowland rice farming in particular. Mulyasa (2002) suggests that the development of thinking skills occurs with increasing age. Based on the condition of farmers who are more dominant with old age, it will also affect the ability of Abenggi Village farmers to manage their farming. Ismilaili et al. (2015) showed that the age factor significantly influenced the adoption of lowland rice PTT innovation.

Based on the research results as described in Table 1, it can be seen that farmers dominated the education level of respondents in Abenggi Village with an elementary school education level (SD), namely as many as 18 respondents $42.86 \%$. This shows that the education level of farmers is still low. Low levels of education can hurt business management ability, acceptance of an innovation, or new technology in lowland rice farming. When farmers are slow to accept creation in agriculture, productivity and income from the farming they manage will hurt. Analysis of Neonbota and Kune (2016), Sukayat and Rumna (2018), the education variable significantly affects lowland rice production. See the Table 1:

Table 1 shows that 22 respondents or $52.38 \%$ are over 50 . Some of them $(42.86 \%)$ do not go to school. Twenty-six respondents, or $61.91 \%$, had a household income level of only Rp. 4,000,000. All respondent farmers cultivate land with an area of 0.5 to 1 hectare. This condition indicates that the low-income level can be triggered by a narrow land area, the age of farmers who have entered a nonproductive period, some of whom have not completed formal education. Phahlevi (2013) suggests that farmers' income can be influenced by land area, age, and level of education of farmers. 
Table 1 Identity of lowland rice farmer respondents in Abenggi Village, Landono District

\begin{tabular}{clrr}
\hline No & \multicolumn{1}{c}{ Respondent Identity } & Amount & Percentage (\%) \\
\hline 1 & Umur (Tahun) & & \\
& $30-40$ & 9 & 21,43 \\
& $41-50$ & 11 & 26,19 \\
& $>50$ & 22 & 52,38 \\
\hline 2 & Pendidikan & & \\
& Tidak Sekolah & 9 & 21,43 \\
& SD & 18 & 42,86 \\
& SMP & 1 & 2,38 \\
& SMA/Sederajat & 14 & 33,33 \\
\hline 3 & Pendapatan rumah tangga (Rp) & 12 & 28,57 \\
& 3.000.000 & 26 & 61,91 \\
& 4.000.000 & 4 & 9,52 \\
& 5.000 .000 & 1 & \\
& Luas lahan garapan (Ha) & & 2,38 \\
& $<0,5$ & 40 & 95,24 \\
& $0,5-1$ & 1 & 2,38 \\
& $>1$ & & \\
\end{tabular}

Based on the research results as described in Table 1, it can be explained that most of the respondents in Abenggi Village, namely 40 respondents or $95.24 \%$ have a land area ranging from 0.5 to $1 \mathrm{Ha}$.Basriwijaya et al. (2016), States that most lowland rice farmers, or $70 \%$ of the respondents, have a rice field area of only 0.5-1 Ha. Thus, the production level that farmers will achieve will be lower than the level of output achieved by farmers with a broader area of land. This means that the land area will be directly proportional to the level of lowland rice production. This has been proven in several studies, such as Rumintjap and Muis (2014), Andrias et al. (2018), Ikhsan et al. (2016), Sukayat and Rumna (2018), Damayanti et al. (2014), and Nasarudin and Muis (2016) stated that land area has a very significant effect on lowland rice farming production.

\section{Forms of Empowerment Programs \\ 1. Capital assistance}

Capital is goods or money which, together with land production factors and labor, produce new goods in agricultural products Mubyarto (1989). Furthermore Daniel (2004) argues that a lack of capital causes a lack of input, which creates a risk of failure or low returns to be received. Based on the explanations of several experts, it shows the critical role of capital in lowland rice farming. Analysis Sukayat and Rumna (2018) show that working capital variables significantly affect farmers' productivity and income in lowland rice farming. This means that the availability of capital is beneficial for farmers in lowland rice farming.

Based on the research results, since 2013, the government has distributed capital assistance to lowland rice farmers in Abenggi Village through the Agricultural Agribusiness Development program (PUAP). Every three farmer groups will be combined into one group to get capital assistance of $\mathrm{Rp} 100,000,0000$. Furthermore, the farmer group manages the fund with a savings and loan scheme and a loan interest of 1\%. Farmers in Abenggi Village will use capital assistance to provide seeds, fertilizers, and pesticides production facilities. This includes tractor rental, and the cost of milling grain comes from the service offered by the government.

The capital referred to in this research is capital assistance in cash, which will be used in lowland rice farming. Farming capital plays an essential role in financing lowland rice farming in Abenggi Village. The research results by Hermawan (2018) show that additional PUAP money contributes to the financing structure of lowland rice farming, reaching $33.96 \%$. Business capital affects the motivation of farmers to run their farms. Based on the research of Hermawan and Harmi (2013), money affects the cause of farmers in rice farming. Neonbota and Kune (2016) state that capital has a significant effect on lowland rice production, each additional $1 \%$ of the money will increase rice production by $0.418 \%$.

The capital assistance provided by the government is expected to increase the quality and quantity of lowland rice production in Abenggi Village. This refers to the research of Hermawan and Andrianyta (2013). With the support of BLM PUAP funds, the need for production input is fulfilled, thus encouraging an increase in lowland rice productivity by almost 2 tons/ha. 


\section{Infrastructure development assistance}

Based on the study results, all respondents stated that the government had built infrastructure in lowland rice farming in irrigation facilities, farming roads, and grain drying facilities. Irrigation facilities have been constructed since the local community arrived in Abenggi Village through the transmigration program. All respondents stated that they had benefited from the infrastructure provided by the government. Prayoga and Sutoyo (2017) state that assistance provided by the government in agricultural machinery, seeds, and fertilizer subsidies can increase rice farming income.

Even though irrigation facilities are available, the minimal water availability has resulted in farmers in Abenggi Village having difficulty meeting their irrigation needs for paddy fields. Given that water is a very vital requirement in lowland rice farming. Fuadi et al. (2016) argued that the need for paddy water with conventional water treatment is greater than the SRI (System of Rice Intensification) water supply system.

The minimal water availability has resulted in farmers in Abenggi Village experiencing losses due to deficient lowland rice production. Of course, this low production is caused by the minimal availability of water. As stated by Purba (2011), the right amount of water will stimulate plant growth and increase the efficiency of water use to increase the area of irrigated plants.

\section{Institutional development}

According to Suradisastra (2016), in the life of the farmer community, the position and function of farmer institutions are part of social institutions that facilitate social interaction in the community. The urgency of the existence of farmer institutions is then explained by Anantanyu (2011), which states that the presence of farmer institutions in rural areas has contributed to the acceleration of socio-economic development and accessibility of farmer information and facilitating stakeholders in facilitating and strengthening farmers.

This study only examines the institutions in lowland rice farming, does not examine the institutions that regulate other social activities. Based on the research results, a unique institution for lowland rice farming has been established in Abenggi Village. The institution in lowland rice farming is actualized by forming farmer groups or farmer group associations. The joint name of the farmer group in Abenggi Village is Sri Rejeki. The farmer groups consist of Budi Karya, Bumi Lestari, Kulon Rejo, Karya Muda and Ora Et Labora. Farmer groups still actively developing lowland rice farming consist of Budi Karya, Sri Rejeki, and Bumi Lestari farmer groups. The formation of these farmer groups is carried out through a legal administrative process, which is outlined in the form of a Decree (SK). This farmer group is also registered at the Abenggi Village office and the local extension agency.

\section{Strengthening business partnerships}

Paddy rice farming is a sector that requires various production facilities in the form of superior seeds, fertilizers, pesticides, and adequate equipment to support lowland rice productivity. Based on the research results, the formation of a partnership that rice farmers in Abenggi Village have built is the provision of production facilities in fertilizers, pesticides, and grain milling.

The need for production facilities in fertilizers and pesticides, lowland rice farmers in Abenggi Village have partnered with suppliers or Farmers' Kiosks in Landono II and Wata Benua Villages. Likewise, rice milling is carried out after harvest by milling service providers in Wata Benua Village. There are two units of grain milling services in Wata Benua Village, namely one grinding unit, which belongs to KUD Sinar Permata and belongs to Mr. Nyoman Sukawana. The rental payment for the grain milling service is made in cash.

Lowland rice farmers in Abenggi Village realize the critical role of partnerships in farming. The existence of associations has provided benefits for lowland rice farmers, and namely, lowland rice farmers will obtain production facilities at the right time. Suddin et al. (2016), one of the partnership patterns with farmer groups and the processing industry is that farmers obtain quality seeds and guidance on cultivation techniques and post-harvest handling. So it is hoped that the partnership pattern can increase the productivity and income of lowland rice farmers in Abenggi Village.

\section{Paddy Farmers' Empowerment Level}

The main target of the farmer empowerment program is to increase farmer empowerment in social and economic aspects. In this study, these two aspects are used by several parameters as benchmarks to see whether the empowerment program has had the expected impact.

\section{Social aspect}

Empowerment in social aspects will be analyzed using several parameters described in Table 2. The first parameter shows that all respondents stated that the farmer himself determined the 
planting area without any influence from other parties, both family members and fellow farmers. This means that a farmer has made various considerations in deciding the planting area. Both in terms of availability of capital, the number of workers, the ability of a farmer to manage lowland rice farming, and the level of production that can be achieved.

The second and third parameters show that most farmers still follow the suggestions or considerations of other parties. Lowland rice farmers need information from fellow farmers or extension workers who have sufficient knowledge regarding marketing and the types of seeds that are best used. In this case, farmers do not yet have the empowerment to make decisions on these two parameters. Supposedly, with the empowerment program, farmers should be able to make choices for their farming based on references or information they have.

Table 2. Empowerment of lowland rice farmers in Abenggi Village in social aspects

\begin{tabular}{clccc}
\hline No & \multicolumn{1}{c}{ Parameter } & Own decision & $\begin{array}{c}\text { Other party's } \\
\text { suggestion }\end{array}$ & Amount \\
\hline 1 & $\begin{array}{l}\text { The party that determines the planting } \\
\text { area for lowland rice }\end{array}$ & 42 & - & 42 \\
\hline 2 & $\begin{array}{l}\text { The party that determines the type of } \\
\text { seed }\end{array}$ & 9 & 33 & 42 \\
\hline 3 & $\begin{array}{l}\text { The party who determines where the } \\
\text { crops will be sold }\end{array}$ & 2 & 40 & 42 \\
\hline 4 & $\begin{array}{l}\text { Farmers always decide for themselves } \\
\text { whom to partner with }\end{array}$ & 36 & 6 & 42 \\
\hline 5 & $\begin{array}{l}\text { Farmers can determine for themselves } \\
\text { who will get information on lowland rice } \\
\text { cultivation techniques }\end{array}$ & - & 42 & 42 \\
\hline
\end{tabular}

The fourth parameter shows that as many as 36 respondents stated that they themselves decided whom to partner with. This means that the ability to determine partners in lowland rice farming positively impacts the interactions built into a farmer group in Abenggi Village. This is where one of the benefits of forming a farmer group is that it becomes a place to get or convey the latest information on lowland rice farming.

The fifth parameter shows that all respondents still need advice from other parties to determine whom to get information on lowland rice cultivation techniques. Other parties referred to in this study are fellow farmers who have high knowledge and experience in lowland rice farming. It can be further analyzed that respondents do not yet have the empowerment to build relationships with other parties to obtain necessary information. This helplessness will give rise to a character of a farmer who will always depend on others and not be independent. Farmers will continue to use conventional cultivation techniques without innovating or adopting new technology.

\section{Economic aspects}

Analysis of the level of empowerment in the economic aspect uses several parameters as described in Table 3. Based on the first parameter, addressing as many as 40 respondents stated that this resulted from deliberation with family members. The profession as a farmer becomes his own choice based on the considerations of each farmer. These considerations include land availability, facilities, and infrastructure, possessed knowledge and technology, sources of farming capital, number of workers, and future hopes in lowland rice farming.

The second parameter shows that 37 respondents stated that the types of needs that are important to be met result from deliberations with family members. This does not mean that farmers do not have the power to determine themselves. However, considering the costs involved, there must be an agreement with family members. Farmers are aware of the family's economic conditions, so to fulfill the family's needs, they must prioritize the most critical needs.

Based on the third and fourth parameters, 41 respondents made their own decisions regarding these two parameters. In this case, farmers already have a good level of empowerment, meaning that the problem of the cost of living for the farming family can determine their ability. Farmers do not need to ask for consideration from family or other people to determine the cost of living. Determining the total cost of living for a farming family uses several reviews. Among them are the amount of income per month, the number of family members, the diversity of types of family needs that are most important to be fulfilled, and the risks that will be accepted if there are needs that are not met. 
Table 3. Empowerment of lowland rice farmers in Abenggi Village in economic aspects

\begin{tabular}{clccc}
\hline No & \multicolumn{1}{c}{ Parameter } & $\begin{array}{c}\text { Own } \\
\text { decision }\end{array}$ & $\begin{array}{c}\text { Other party's } \\
\text { suggestion }\end{array}$ & Amount \\
\hline 1 & The party who determines the profession as a farmer & 40 & 2 & 42 \\
\hline 2 & $\begin{array}{l}\text { The party that determines the most critical family } \\
\text { needs to be met }\end{array}$ & 5 & 37 & 42 \\
\hline 3 & $\begin{array}{l}\text { The party who determines the number of living costs } \\
\text { in the family }\end{array}$ & 41 & 1 & 42 \\
\hline 4 & $\begin{array}{l}\text { Parties determine the amount of future savings for } \\
\text { the family }\end{array}$ & 41 & 1 & 42 \\
\hline
\end{tabular}

Likewise, farmers also use several considerations regarding the amount of future savings. The data includes the income, cost of living, and needs that must be met as soon as possible. After various basic needs are met, the remaining income earned by farmers will be used for savings or to meet other requirements. This is in line with the research of Ibrahim (2018); Samaduri (2020) which suggest the factors that influence farmers to save part of their income.

\section{CONCLUSIONS AND SUGGESTION}

Based on the results of this study, it can be concluded that the form of the rice farmer empowerment program in Abenggi Village consists of capital assistance through the Agricultural Agribusiness Development Program (PUAP), the provision of infrastructure such as irrigation facilities, farming roads, and grain drying places. The indicator of farmer empowerment in Abenggi Village is still relatively low, which can be seen from the ability of farmers to understand themselves and their potential, plan and overcome future conditions, direct themselves, and negotiate and make decisions in the farming process. Lowland rice farmers in Abenggi Village are empowered on the economic aspect, but not yet on the social part.

\section{REFERENCES}

Anantanyu, S. (2011). Farmer Institutions: Their Roles and Capacity Building Strategies. UNINTERESTING, 7(2), 102-109.

Andrias, Darusman, A. A., Yus, \& Ramdan, M. (2018). The Effect of Land Area on Production and Income of Paddy Rice Farming (a case in Jelat Village, Baregbeg District, Ciamis Regency). AGROINFO GALUH Student Scientific Journal, 4(1), 552-529. https://doi.org/doi:10.25157/jimag.v4i1.1591

Anggoro, \& Apriyanto, D. (2010). The influence of social capital, community empowerment, and social assistance on business resilience. The influence of social capital, community empowerment, and social assistance on business resilience.

Basriwijaya, Zain, K. M., \& Hedra, P. (2016). The Relationship between Farmer Characteristics and Paddy Rice Production in Rambah Tengah Barat Village, Rambah District, Rokan Hulu Regency. (Scientific Articles, Issue.

BPS Konawe Selatan. (2018). South Konawe in Figure 2018. In. Figure 2018. ISSN 2502-9088. Catalog Number 1102001.7405. Publication Number 74050.1803.

Cahyono, E., Sukidin, \& Kantun, S. (2018). Community Empowerment Models of Tourism Village Based on Superior Commodities: Realizing Economic Resilience. Journal of Distribution Science, 16(11), 29-36.

Damayanti, M., Yusma, \& Elwamendri. (2014). Analysis of the factors that influence the production of lowland rice farming in Batang Asai District, Sarolangun Regency. Journal of Socio-Economic Business, 17(1), 89-21. https://doi.org/doi:10.22437/jiseb.v17i1.2795

Daniel, M. (2004). Introduction to Agricultural Economics. PT. Bumi Aksara.

Fischer, A., \& McKee, A. (2017). A question of capacities? Community resilience and empowerment between assets, abilities, and relationships. Journal of Rural Studies, 54, 187-197.

Fuadi, N. A., Purwanto, M. Y. J., \& Tarigan, S. D. (2016). Kajian Kebutuhan Air Dan Produktivitas Air Padi Sawah Dengan Sistem Pemberian Air Secara Sri Dan Konvensional Menggunakan Irigasi Pipa. Jurnal Irigasi, 11(1), 23-32. https://doi.org/10.31028/ji.v11.i1.23-32

Hermawan, H., \& Andrianyta, H. (2013). Peran tambahan modal terhadap pendapatan usahatani padi di Kabupaten Blitar dan Ngawi, Jawa Timur. Jurna I Pengkajian dan Pengembangan Teknologi Pertanian, 16(2), 132-139. 
Hermawan, H., \& Harmi, A. (2013). The role of additional capital on rice farming income in Blitar and Ngawi Regencies, East Java. Journal of Agricultural Technology Assessment and Development, 16(2), 132-139.

Hermawan, M. A. (2018). The Effect of Education Level and Work Experience on Work Productivity in Islamic Economic Perspective (Study on Employees of PT. Indokom Samudra Persada). UIN Raden Intan Lampung.

Hutomo, M. Y. (2000). Community empowerment in the economic field: Theoretical review and implementation. Bapennas.

Ibrahim, I. (2018). Analysis of Factors Affecting Farmers' Motivation in Saving at the Bank (Case Study on Pepper Farmers in Ticap Village, Towuti District) IAIN Palopo]. Palopo.

Ikhsan, Zakiah, M., \& Rahmaddiansyah. (2016). he Effect of Capital Ownership on the Income of Rice Farmers in Sakti District, Pidie Regency. Scientific Journal of Agricultural Students Unsyiah, 1(1), 427-438. https://doi.org/doi:10.17969/jimfp.v1i1.1221

Ismilaili, Purnaningsih, N., \& Asngari, P. S. (2015). Tingkat Adopsi Inovasi Pengelolaan Tanaman Terpadu (PTT) Padi Sawah di Kecamatan Leuwiliang, Kabupaten Bogor. Jurnal Penyuluhan, 11(1), 49-59.

Mangowal, J. (2013). Empowerment of Farmer Community in Improving Rural Economic Development in Tumani Village, Maesaan District, South Minahasa Regency. Govermance, $5(1)$.

Mubyarto. (1989). Introduction to Agricultural Economics. LP3S.

Mulyasa. (2002). Competency Based Curiculum: Characterisic, and Implementation.

Nasarudin, A., \& Muis, A. (2016). Analysis of Production and Income of Paddy Rice Farming with a Table Cropping Pattern in Dolago Village, South Parigi District, Parigi Moutong Regency. e-J Agrotechnical, 4(4).

Neonbota, \& Kune, S. L. (2016). Factors Affecting Rice Field Farming in Haekto Village, East Noemuti District. Journal of Dry Land Agribusiness, 1(3), 32-35.

Pranadji, T. (2006). Strengthening Social Capital for Empowering Rural Communities in Dry Land Agroecosystem Management. Journal of Agro-economy, 24(2), 178-206.

Prayoga, A., \& Sutoyo. (2017). Productivity and Income of Paddy Paddy Farming Impact of Agricultural Machine Tools Assistance Program, Seeds and Fertilizers in Malang Regency, East Java Province. Journal of Agricultural Sciences, 24(1), 1-9. https://doi.org/doi:10.36626/jiip.v24i1.228

Purba, J. H. (2011). Needs and methods of providing irrigation water for lowland rice (Oryza sativa L.). Journal of Science and Technology, 10(3), 145-155.

Rumintjap, V., \& Muis, A. (2014). Analisis Produksi dan Pendapatan Usahatani Padi Sawah di Desa Pandere Kecamatan Gumbasa Kabupaten Sigi Provinsi Sulawesi Tengah. e-J. Agrotekbis, 2(3).

Sadono, Sumardjo, Gani, S. D., \& Amanah, S. (2014). Farmer Empowerment in The Management of Rice Farming in Two Districts in West Java. Journal of Rural Indonesia (JORI), 2(1).

Samaduri, L. (2020). The Motivation of Talima A Village Farmers to Save at Bank Rakyat Indonesia (BRI). JOURNAL OF AGROBIZ, 1(2), 28-39.

Suddin, A. F., Ayesha, I., \& Elizabeth, R. (2016). Akselerasi Implementasi Kelembagaan Partnership Untuk Pengembangan Agribisnis Dan Pensejahteraan Petani Hortikultura. Journal of Social and Economics Research, 1(1), 1-11.

Sukayat, H., \& Rumna. (2018). Analisis Pendapatan Dan Faktor-Faktor Sosial Ekonomi Yang Mempengaruhi Hasil Produktivitas Pengelola Usahatani Padi Sawah Kabupaten Cianjur. JIMFE (Jurnal Ilmiah Manajemen Fakultas Ekonomi), 3(2), 37-48. https://doi.org/10.34203/jimfe.v3i2.645

Suradisastra, K. (2016). Strategi Pemberdayaan Kelembagaan Petani. Forum Penelitian Agro Ekonomi,

Widjajanti, K. (2011). Model Pemberdayaan Masyarakat. Jurnal Ekonomi Pembangunan, 12(1), 1527. 